\title{
ФРІЦ ЛАНГ: СИМВОЛІКА АРХІТЕКТУРИ
}

У статті йдеться про одного з найвідоміших кіномитців світу, класика експресіонізму Фріиа Ланга. Розглядається саме той період творчості мития, коли склалися основи його стилістики, які згодом збагатили світовий кінематограф у иілому.

Ключові слова: експресіонізм, архітектурні ритми, образ маніпулятора, студійний пейзаж, міфологічне мислення.

В статье идет речь об одном из известнейших кинематографистов, классика экспрессионизма Фрице Ланге. Рассматривается тот период творчества твориза, когда сложились основы его стилистики, которая обогатила со временем весь мировой кинематограф.

Ключевые слова: экспрессионизм, архитектурные ритмы, образ манипулятора, студийный пейзаж, мифологическое мышление.

The article is about one of the most famous filmmakers in the world, classic of expressionism Fritz Lang. It considers the period of his work, when the basis of style was formed, which later enriched the world cinema in general.

Keywords: expressionism, architectural rhythms, image of manipulator, studio landscape, mythological thinking.

Фріц Ланг належав до тієї нечисленної когорти всесвітньо відомих митців, котрі, рухаючись разом із часом, залишалися вірними собі, своїм творчим принципам і моральним настановам. Досягнувши мистецьких вершин в «золоті часи» німецького кіно, створивши фільми, впливи яких залишалися відчутними протягом усієї істоpiї кіно, він зважився на кроки, котрі свідчили не лише про його творчу сміливість, а й про непохитну громадянську позицію. Він - один з небагатьох німецьких кінематографістів, який зважився сміливо вступити у сфери звукового кіно, продемонструвавши віртуозне володіння новими виражальними засобами кінематографа, створюючи на екрані вражаючі звукозорові образи.

Другий крок його був достойний особливої поваги. Ланг, ставши наприкінці $20-\mathrm{x}$ - на початку $30-x$ років одним 3 провідних німецьких режисерів, знайшов у собі мужність не пристати на пропозицію, від якої, здавалося, неможливо було відмовитись. Після приходу нацистів до влади сам Геббельс запропонував йому стати на чолі німецької кінематографії. Втім, Ланг відповів не словами, а вчинком. Поклавши до валізи свій останній фільм, знятий у Німеччині, «Заповіт доктора Мабузе», він узяв квитки на потяг до Парижа, щоб почати творче життя 3 чистого аркуша. Власне, зробив крок у невідоме. Творчість Ланга у еміграції, спочатку у Франції, потім у США - предмет, вартий детального, уважного аналізу. Режисер не лише вписався в складну і непросту картину американського кінематографа, а й привніс в неї свої неповторні інтонації, свій вишуканий стиль, навіть працюючи в таких традиційних жанрах, як вестерн або «нуар».

I все ж можна 3 певністю твердити, що зоряні часи Ланга - це 20-ті роки, розквіт експресіонізму - напряму, чиї імпульси та впливи й досі має в собі світовий кінематограф.

Отже, прихід Ланга в кіно був досить типовим для тих часів, коли в лави кінематографістів вливалися люди «нізвідки», ті, що не мали жодних стосунків до молодого, але вже шалено популярного мистецтва.

Фріц Ланг, молодий австрійський офіцер, ще перебуваючи в шпиталі, де він лікувався від тяжких поранень, отриманих на фронті Першої світової війни, починає писати сценарії, якими досить 
несподівано для нього самого зацікавилися професіонали. Після одужання автор-початківець отримує пропозицію стати самому до камери. Його перший фільм «Харакірі» (вільна інтерпретація сюжету «Мадам Батерфляй», 1918 р.) не зберігся. Про багатосерійний фільм Ланга «Павуки», 3 якого він устиг відзняти лише дві серії - «Золоте озеро» i «Корабель 3 діамантами», воліють згадувати лише як про неприємну перешкоду. Бо саме робота над цими стрічками не дала йому можливості взятися до режисури над сценарієм К. Майєра і Г. Яновіца «Кабінет доктора Калігарі». Проте, на нашу думку, ці невибагливі пригодницькі стрічки варті уваги. Недарма ними цікавилася одна 3 найбільш глибоких дослідниць німецького кінематографа Лотте Айснер.

Звичайно, в цих перших «пробах пера» досить чітко простежуються впливи, як пригодницької літератури Карла Мая і Едгара Воллеса, так і тогочасного жанрового кінематографа. Тут згадуються як знамениті французькі серіали Л. Фейада, 3 їх злочинцями-суперменами, так і вестерни, в яких з'являється героїчний і таємничий самотній вершник, що може протистояти підступному і могутньому злу.

Силуети цих постатей, що в «Павуках» будуть ще досить схематичними, від фільму до фільму набиратимуть психологічної обумовленості та переконливості. Якщо вчинки таємничої Ліо Ша (свого роду інваріант Ірми Веп з фейядівських «Вампірів»), так і залишаються нерозгаданими, - чи це воля до влади, чи прагнення фантастичного багатства, — то в наступних фільмах Ланг дедалі наполегливіше прагнутиме проникнути в психологію злочину.

Лотте Айснер також справедливо зауважує, що знахідки режисера, які мали місце в його перших фільмах, не зникають, а набувають свого розвитку у подальших його стрічках. Скажімо, таємничі печери, підземні лабіринти, де злочинці-«павуки» ховають свої багатства, глядач побачить і в «Нібелунгах» (скарби Альберіха), і в «Метрополісі» (катакомби, де божевільний учений провадить свої досліди). Так само і постать дивака, «безумця від науки» буде ескізно накреслена вже в цьому ранньому серіалі. Саме до нього прийде головний герой фільму з проханням розшифрувати таємничий напис.

Погодимося 3 думкою Лотте Айснер в тому, що в «Павуках» ми вже зустрічаємо типові елементи кінематографа Ланга.

Втім, «справжній» Ланг починається, на нашу думку, з його суто експресіоністської стріч- ки «Втомлена смерть» (1921). Ланг належав до тих кіномитців, які полюбляли заперечувати свою приналежність до цього напряму. Та тут, мабуть, істина навіть не в суб'єктивному відчутті митця, а в тій об'єктивній картині, що являє собою його екранний доробок, який став об'єктом дослідження таких видатних мистецтвознавців, як Зігфрід Кракауер і Лотте Айснер. До того ж, уже в 1960-х роках режисер не міг не визнати, що експресіонізм справив на нього значний вплив $[5,56]$.

Окремо варто зупинитися на співпраці Ланга зі сценаристкою Теа фон Гарбоу, яку досить часто історики кіно презентують як свого роду «злого демона» митця, що від нього йшли всі недоладності та прорахунки в його фільмах. На думку Б. Ейзеншица, Гарбоу проявила себе як прекрасна сценаристка. «Вона вміє виділяти з легенд або популярної літератури основні сюжетні лінії і надавати їм драматичності, притаманної кіно» $[6,57]$.

Підтримуємо думку тих дослідників, які вважали, що Гарбоу, не будучи надто обдарованою і оригінальною письменницею, разом 3 тим майстерно розробляла фабулу, характери, сюжетні перипетії, саме з урахуванням перенесення літературного твору на екран. Ї̈̈ професіоналізм сценаристки був поза сумнівом. Інакше як пояснити, що всі свої найкращі фільми німого періоду Ланг створив у співавторстві 3 нею. I не лише Ланг, а й інші режисери, серед яких була така яскрава особистість, як Ф. В. Мурнау.

«Втомлена смерть» - фільм в якому вже із захоплюючою виразністю прозвучать основні мотиви творчості Ф. Ланга часів Великого Німого i, передусім, тема невмолимості долі.

Ці мотиви притаманні експресіоністському напрямові в цілому. Вже в «Кабінеті доктора Калігарі» сомнамбула Чезаре сприймається зі своїми похмурими пророцтвами як вісник долі. Він сам i виконує iї злу волю. Часто проходить повз увагу знижене іронічне звучання цієї теми. Адже на ярмарку всі охочі можуть купити квиточок з передбаченням майбутнього, що їх витягає мавпочка катеринника.

Композиційно фільм було побудовано з «обрамляючого» сюжету і трьох новел як свого роду екранну фугу, де в різних тональностях і звучить переконаність у неможливості вирватись 3 лабет долі. I вже в цьому фільмі стає зрозуміло, якого значення надає режисер взаємодії персонажів і середовища. Можна сказати, ця тенденція притаманна експресіоністському кінематографові як такому. Творення середовища, атмосфери дії характерне для митців, що не бажали просто копіювати 
природу, а йшли шляхом її відтворення, згідно зі своїм внутрішнім баченням.

У цьому аспекті — найвиразніший приклад «Кабінет доктора Калігарі», де три художники експресіоністської групи «Штурм» - Вальтер Рьоріг, Герман Варм і Вальтер Райман створили «світ очима безумця». Двоє з них працювали і над фільмом Ланга. Та тут митці відійшли від підкресленої умовності фільму Р. Віне і відтворили ідилічне німецьке містечко епохи романтизму. Але рука невблаганної долі простягається і сюди. «Батьки» міста за келихом вина обговорюють дивну подію: якийсь таємничий незнайомець купив землю за цвинтарем і огородив її височезною стіною. Та ось 3'являється і він, підсідаючи до столика молодят, які щойно приїхали до міста разом 3 ним у поштовій кареті. Дівчина з острахом дивиться на нього, розливає вино і поспішає до кухні, щоб привести в порядок сукню. Та, повернувшись, не знаходить ні незнайомця, ні свого нареченого. Марно дівчина блукає містом, ходить біля грандіозної стіни, вкритої таємничими знаками. Ця велична споруда ніби перекреслює затишне містечко, що поринуло в сон. Такий архітектурний дисонанс задає свого роду тональність протиставленню: маленька людина і невблаганна сила долі.

У цьому фільмі Ланг і його художники-постановники створять один з найвиразніших експресіоністських інтер'єрів - комірчину аптекаря. Всі предмети, що заповнюють полиці в ній, випромінюють фосфоресцююче світло, що неначе окреслює їх силуети. Випивши отрути, дівчина потрапляє в храм смерті, де світяться, потроху згасаючи тисячі свічок, і кожна з них - це людське життя. Таємничий незнайомець - він же янгол смерті, зглянувшись на благання дівчини, дає ій шанс повернути коханого. Вона має не дати згаснути трьом свічкам, подорожуючи 3 нареченим різними країнами в різні епохи.

Згадаймо тут слова Лотте Айснер: «По своїй суті Ланг — архітектор». Разом з тим не можна не відчути, що певні архітектурні мотиви залишають режисера майже байдужим. Світ чарівних казок Шехерезади сприймається скоріше як ілюстрація до дитячих книжок. Водночас режисер дає волю своїй фантазії і витонченому смаку в «ренесанівських» епізодах.

Світло тут стає «фактором оформлення простору» (Р. Курц), що характерно для експресіоністського кінематографа в цілому. Ланг розташовує дію на кількох площинах, що було притаманне тогочасному авангардистському театрові (зокрема Л. Курбаса).
У вихорі карнавалу мчить, охоплений веселощами натовп, спускаючись сходами, що ведуть до самого каналу, де оксамитово мерехтить вода. Режисер використовує в цих кадрах червоний колір (символ руйнації), що ховає в собі амбівалентні смисли. Це і колір буйних розваг, і загроза близької загибелі. Від підступного удару кинджалом загине коханий дівчини.

Якщо в епізоді карнавалу сходи використовуються для побудови динамічної мізансцени, то сходи, що ведуть до таємничих дверей у стіні, мають вже символічний характер. Здається, проникнути за високий-високий мур немає жодної надії. Та згодом, коли своїм благородним учинком порятунком дитини під час пожежі - дівчина заслужить на зустріч з юнаком, десь угорі стіни відчиняються вузькі «готичні» двері, з яких ллється тихе, спокійне світло. Дівчина поволі піднімається сходами назустріч знову знайденому коханню. А світло, посилюючись, заповнює зображення, роблячи і сходи, і постаті героїв майже прозорими і нереальними.

Лотте Айснер спостерігала в цьому епізоді відчутний вплив сценічних рішень Макса Рейнгардта, який у своїх спектаклях, розташовуючи джерела світла десь угорі, його потоками заливав сцену. Критики називали видатного німецького режисера майстром світла.

Повернемось до думки, що символічна навантаженість архітектури у Ланга мали широкий кінематографічний контекст. Місто в «Кабінеті доктора Калігарі» — «світ очима безумця», що несе в собі незбагнену містичну небезпеку.

Не менш таємничим постає місто-гетто в «Големі» (1920 р., реж. П. Галлен, П. Вегенер). Саме архітектурне рішення цього фільму примушує Лотте Айснер віднести його до експресіоністського напряму. I багато в чому завдяки роботі художника Ганса Пьольціга. Декоратор не йшов шляхом тієї асолютної умовності, котра притаманна художникам фільму Р. Віне.

Проте його місто в «Големі» не $\epsilon$ реалістичним відтворенням середньовічної архітектури. Створений фантазією митця простір, дахи будинків, що тісняться за стінами гетто, повторюють гостроконечні шляхи його мешканців, і коли вони йдуть вузькими, покрученими вуличками, здається, що і будівлі .

Ці будівлі, на думку Р.Курца, не $\epsilon$ відтворенням реального готичного міста, а свого роду «втіленням готичного сновидіння». Дослідник експресіонізму бачить у творіннях Пьольціга «ритмічно відчуту архітектуру, могутнє архітектурне осмис- 
лення силових полів і взаємозв'язків - виражене засобами почасти експресіоністського, почасти готичного стилю» $[1,33]$.

Та ці «архітектурні ритми» готики принципово відрізняються від тих, що їх запропонує далі Ланг у своєму «Метрополісі».

Вслід за «Втомленою смертю» режисер вдається до постановки стрічки, котра начебто покликана йому компенсувати «неучасть» у втіленні на екрані сценарію К. Майєра і Г. Яновіца «Кабінет доктора Калігарі». Знов-таки у співпраці з Теа фон Гарбоу він ставить фільм «Доктор Мабузе, гравець».

На перший погляд сюжетна схема і центральна постать стрічки більш наближаються до фейядівського «Фантомаса», ніж до містичного персонажа фільму Р. Віне. I разом 3 тим подібність до Фантомаса суто поверхова. Головний герой серіалу Луї Фейяда вчиняє свої злочини з єдиною метою - збагачення. Майстерна зміна масок і засоби обману представників закону нагадують скоріше гру, нехай підступну і небезпечну.

Доктор Мабузе - інший. Для нього найголовніше - маніпулювання людиною, перетворення іiі на покірну маріонетку, у виконавця волі свого повелителя. До того ж у підзаголовках двох серій неоднозначно вказується на те, що цей маніпулятор і злочинець - сучасник глядача, що він, вершачи свої злочини, знаходиться десь поруч.

Перша частина диптиха мала назву «Образ часу», друга — «Inferno - люди часу». Сам Ланг вважав: успіх його фільму визначався тим, що він «ставав образом або точніше - документом епохи... Фільм як документ епохи (різновидом і почасти попередником такого роду картин був «Доктор Мабузе») показує або повинен показувати сучасну людину з тим самим ступенем гіперболізації, як я намагався створити це в «Нібелунгах». Не просто якусь людину 1924 року, а саме людину 1924 року. Образ людини потребує подібної гіперболізації у зображенні почуттів і вчинків навіть тоді, коли він сам жалюгідний і дрібний. Він потребує п'єдесталу стилізації, так само, як цього потребували минулі віки. Адже пам'ятники не ставлять на голий асфальт: їх піднімають над головами перехожих, щоб надати їм більшої сили впливу» $[5,73]$.

Справді, митець прагне створити не просто абстрактний образ тирана-маніпулятора людськими долями, а й особистість, яка живе людськими пристрастями і почуттями, хоч якими б ницими вони були. Мабузе 3 хвилюванням стежить 3 годинником в руках за тим, як проходять його злочинні «операції», впадає у відчай, коли вони зриваються, святкує свої перемоги. Він упивається своєю владою над коханкою, танцівницею Кара-Кароцою, примушуючи іiі накласти на себе руки, коли жінка стає йому на заваді. Він робить аристократа Тольда своєю безвольною іграшкою, але й сам великий гіпнотизер Мабузе втрачає владу над собою, закохавшись у графиню Тольд.

Ланг занурює події в ту напівбожевільну атмосферу післявоєнної Німеччини, коли злиденність та інфляція межували 3 фантастичними неправедно нажитими багатствами, суспільство здригалося від кривавих вуличних сутичок, а демагоги всіх кольорів намагалися спокусити нездійсненними обіцянками. Все це заломлювалося в напівфантастичному світі лангівської картини.

Безумний гедонізм обертається фатальними пороками: наркоманією, пияцтвом, сексуальними відхиленнями. Саме в цьому суспільному хаосі почувається цілком комфортно Мабузе, міняючи свої маски, граючи людськими долями. В картині Ланга здається знову виникне «світ очима безумця», але не той стилізований художниками-експресіоністами Хольстенваль, що його ми бачимо в «Кабінеті доктора Калігарі», а цілком реальне сучасне місто, проте зловісні темні провулки змусять глядача згадати заплутані вулички Хостенваля.

Декорації художника Отто Хунте (а це переважно інтер'єри) вводять глядача і в цілком конкретний світ багатих апартаментів у стилі віденського Сецессіона, і в світ страшних підвалів і катакомб, де ховаються злочинні виконавці намірів доктора, i, головне, - казіно, де панує Мабузе з рулеткою, що невпинно кружляє, неначе затягуючи у свій вир гравців.

Візуальний мотив кола раз у раз спливає у фільмі - це і згадана вже рулетка, і орнамент на підлозі гральної зали, і білі руки учасників спіритичного сеансу на круглому столі.

Кракауер звертає увагу на спорідненість Мабузе 3 цим хаотичним світом. Бажаючи втягнути прокурора Венка у свою гру, Мабузе з'являється у вигляді зловісного старого, що не зводить з Венка очей під час гри. Далі дослідник вказує на кадри обличчя Мабузе, що маленькою яскравою плямою спалахує на чорному екрані, потім зі страшною швидкістю летить на глядача, розростаючись і заповнюючи екран до рамки, жорстокі владні очі доктора Мабузе пильно вглядаються в глядацьку залу. Мабузе в кадрі - породження пітьми, яка пожирає світ, йому підвладний $[4,98]$.

Важливо, що серед більшості жертв Мабузе - ті, хто вступив у його світ зла і тому стає його легкою здобиччю. 
Можна сказати, що в «Докторі Мабузе» Лангові вдалося частково довести думку, що він реаліст. Справді безумна і катастрофічна атмосфера післявоєнної Німеччини передана в точних і красномовних деталях. Один з найвиразніших епізодів цього плану - паніка на біржі, що ії спровокував Мабузе. Назва «Доктор Мабузе, гравець» свідчить про те, що він грає не лише в казино, а й там, де вирішуються долі мільйонів, - на біржі. Викрадені його спільниками документи, надруковані фальшиві гроші дають докторові можливість, створивши паніку на біржі, стати власником величезних статків. Операційний зал вщерть заповнений як маклерами, які істерично кричать i жестикулюють, так і достойниками у високих циліндрах, які теж поступово втрачають владу над собою, очікуючи завершень біржових торгів. I над усім натовпом височить постать одного з біржових ділків (чергова машкара Мабузе). Стрілки величезного годинника на стіні наближаються до доленосної години. Гру закінчено. Мабузе в своїй черговій іпостасі знову виявляється переможцем. Фінальні кадри цього епізоду - спустілий зал, загублені капелюхи, тростинки, рукавички. I над усім цим - невмолимий рух стрілок годинника.

Різні годинники ще не раз 3'являться в кадрі і матимуть у собі символічне навантаження. Вони відлічують не стільки реальний час, як невмолимий рух долі приречених героїв. Такі деталі знов-таки поєднує фільм Ланга 3 експресіоністською стилістикою.

Втім, митець не шукає пояснень подіям, що відбуваються лише в соціумі, його фантазія поринає в містичний світ, котрий таїться за завісою повсякдення. Доктор Мабузе не лише геніальний злочинець, він гіпнотизер, він має таємничі і незрозумілі за законами звичайної логіки важелі впливу на іншого. І от, щоб передати дію цього містичного інструментарію, режисерові й потрібен весь арсенал ескпресіоністських виражальних засобів i, насамперед, освітлення.

Занурюючи у морок обличчя-маску головного героя, камера несподівано вихоплює його променем світла, створюючи враження, що він виникає нізвідки, з якогось незрозумілого таємничого простору.

Суто експресіоністським можна вважати і спіритичний сеанс, де світло вихоплює лише руки, що застигли на круглому столі. Щоправда, режисер трактує це досить іронічно. Медіум, своїми темними підмальованими очима чимось схожа на сомнамбулу Чезаре, з обуренням перериває сеанс і заявляє, що серед запрошених хтось не вірить їй. Цим скептиком виявляється графиня Тольд.
I, звичайно ж, згаданий епізод у палаці графа Тольда, де Мабузе постає у своій демонічній сутності. Але й тут Ланг дозволяє собі іронізувати. Зібрання картин графа Тольда - то твори експресіоністів. На запитання, як йому подобається ця колекція, Мабузе відповідає, що для нього все це лише гра.

У картині Ланга вже досить чітко оформлюється одна 3 основоположних міфологем - опозиція верху і низу. Творячи свої безчинства у реальному світі, Мабузе свій простір знаходить у підземеллях, у страшних катакомбах, де він ховається разом зі своїми скарбами. Там і дістає його рука правосуддя, там він, втративши владу над людьми, втрачає розум, а верстат для друкування фальшивих банкнот перетворюється в уяві божевільного Мабузе на чудовисько, що тягнеться до нього своїми пазурами.

Якщо ми бачимо у фіналі фільму вже божевільного Мабузе в його страшних підземеллях, то герой наступного фільму Ланга покидає світ мороку, щоб зробити рішучий крок назустріч світлу. Втім, до Мабузе Ланг звернеться ще не раз. Але після першого фільму про злочинного доктора режисер виведе на екрани сонцесяйного Зігфріда, героя німецького національного епосу «Нібелунги». Своє прагнення поставити цей фільм Ланг пояснить бажанням, за свідченням Кракауера, створити «щось глибоконаціональне, відомий парафраз самої "Пісні про Нібелунгів", він, своєю чергою, може вважатися справжнім проявом німецької душі». Режисер не мав на меті конкурувати із «зовнішньою грандіозністю амриканського історико-костюмного фільму», а прагнув «прилучити світ до німецької кулььтури» [4, 109].

Закид кінознавця, буцімто фільм випередив гебельсівську пропаганду, здається нам абсолютно безпідставним, і це Ланг довів своєю подальшою творчою біографією.

Фільм «Нібелунги» починається 3 епізодів, дія яких розгортається в похмурих печерах і хащах пралісу. Самі декоративні композиції несуть у собі прихований символічний зміст. Світлий лицар Зігфрід повинен вирватись із підземного царства, щоб звершити свої подвиги. Освітлення вихоплює проміннями постать героя, який і протистоїть темряві, в яку занурений підземний світ, наголошуючи тим самим морок підземель. Верхи на білому коні лицар вирушає назустріч своїм подвигам і своїй невмолимій долі.

Знамениті кадри пралісу, гігантські стовбури дерев, на тлі яких ми бачимо вершника, являли собою один з блискучих прикладів декораційного мистецтва. 
Зусиллями художників О. Хунте і Е. Кетельхута праліс було «збудовано» 3 гіпсу, але дерева височіли на тлі відкритого простору в стіні павільйону і тьмяне світло, що пробивалося крізь щільно поставлені стовбури, було цілком реальним. Вершник, який проїздив повз них, раз у раз занурювався у таємничі тумани, котрі вкривають ущелини, де ховаються злі невідомі створіння, що зненацька виринають 3 них.

Цю композицію не раз порівнювали 3 картиною Бьокліна «Німфа на єдинорозі». Алюзії на твори живопису виникають у фільмах Ф. Ланга: у «Втомленій смерті» — це Дюрер і Грюненвальд, у «Метрополісі» - Брейгель.

У створенні студійних пейзажів повною мірою проявилась експресіоністська тенденція відмови від копіювання дійсності, створення у павільйоні ландшафтів, який би брав участь у дії, мав цілком певне емоційне звучання.

Лотте Айснер зауважувала, що «створити експресіоністський ландшафт набагато складніше, ніж вибудовувати експресіоністські будівлі» $[1,83]$. Боротьба світла і тіні стає свого роду віддзеркаленням протистояння світлих і темних сил - Зігфріда і підступного короля нібелунгів (нібелунги - діти туману) Альберіха, який, виринаючи з тьмяного болота, міняючи свою подобу, намагається своїми довгими, як голі віти осінніх дерев, пальцями задушити Зігфріда. Переможений Альберіх сподівається купити життя ціною незліченних скарбів, захованих у глибоких печерах. I знову режисер вміщує героя в тьмяний простір підземних переходів, де темрява дедалі відчутніше переважає світло. Майстерно зняті кадри кам'яної чаші зі скарбами, яку підтримують маленькі гноми. Саме в ній знайде Зігфрід чудесний меч, Бальдунг, який зробить його непереможним, а злостивий Альберіх перетворить карликів на кам'яні статуї і сам стане деревиною, що гниє в болотяній воді.

Як одвічна боротьба зі злом трактується поєдинок Зігфріда 3 драконом Фафніром, що відбувається в лісовій хащі. Слід зазначити, що, як на ті часи, цей епізод (дракона приводили в рух кілька чоловіків, що знаходилися всередині чудовиська) знято на досить високому технологічному рівні. Та, головне, в цьому епізоді знов і знов прозвучить тема невмолимості долі. Зігфрід перемагає страшну і могутню силу. Але, здавалось би, зовсім непомітний і незначний випадок передрішить його майбутне. Конаючи, дракон поворухнув хвостом, і з липи злетів крихітний листочок на спину Зігфріда. Герой скупається в крові дракона і стане невразливим до будь-якої зброї. Залишиться маленька цяточка на спині, де прилип листочок. Туди і поцілить спис підступного ворога.

Епізоди у Вормсі, столиці бургундів, Ланг знімає в інший стилістиці. На зміну хаотичним переплетінням печерних переходів, могутніх стовбурів дерев і тяжких валунів, що загороджують входи в підземелля, на зміну тьмяному освітленню, де темрява домінує, приходять чіткі лінії і форми палацу короля бургундів, зі сходами, коридорами і залами. Згадаймо слова Лотте Айснер, що Фріц Ланг — передусім архітектор. Величні споруди освітлені рівним і холодним світлом. Кожна постать в цих грандіозних залах розташована на відповідному місці, i, здається, ніщо не може порушити цей порядок. I трубач на вежі, i воїни охорони зі списами і щитами, і сам король на троні зі своїм почтом, здаються частинами орнаменту, що прикрашає палац. Костюми персонажів, візерунки на них теж набувають чітких геометричних форм. Це дало привід Кракауеру зауважити: «Перед нами торжество орнаментального над людським. Необмежена влада виражається й у тих привабливих орнаментальних композиціях, де використані люди» $[4,112]$.

Попри те, що в архітектурі Вормса панують довершеність і порядок, вона не стає віддзеркаленням рівноваги і гармонії в душах героїв. Навпаки, ми бачимо, як їх охоплюють темні, криваві пристрасті. Якщо світ Вормса - то світ цивілізації, марно сподіватися, що вона втримає людство від жорстоких підступних злочинів. Саме в замку короля Гунтера вступає в дію персонаж, якого можна включити в «галерею тиранів» - васал короля Хаген фон Троньє, постать досить неоднозначна, про що свідчать грим і костюм цієї дійової особи. Він має одне око, а шолом його прикрашений крилами хижого птаха. Цей його вигляд нагадує Одіна, верховного божества германців і скандинавів, що віддав своє око за те, щоб мати змогу передбачити майбутнє. Головне, що поєднує таких персонажів, як Калігарі, Мабузе і Хаген, це пристрасне бажання маніпулювати іншими, позбавити їх власної волі, перетворити на живих маріонеток. Він і розпочинає зав'язувати вузол інтриги, в яку будуть втягнуті долі всіх персонажів фільму. Саме Хаген підкаже королю заручитися підтримкою Зігфріда у «підкоренні» королеви Брунгільди, тим самим штовхаючи героїв на шлях облуди і обману, за що вони заплатять дорогу ціну. Хаген дізнається від легковірної Крімгільди таємницю невразливості Зігфріда. Туди він і поцілить списа, коли Зігфрід на полюванні схилиться над джерелом, щоб напитися води. 
Теа фон Гарбоу, працюючи над сценарієм, акцентувала думку про неминучість розплати за всі вчинені підступи і злочини. Враження, ніби герої увійшли в світ цивілізації, де панують справедливість і право, виявляється оманливим. Епізоди в замку Брунгільди стають ніби попередженням про існування іншого виміру, де правлять дикі пристрасті та інстинкти. Тут знову Ланг і його художники йдуть від архітектури. Якщо будівлі Вормса розлогі, такі, що впевнено розташувались на земній тверді, то замок Брунгільди неначе виростає зі скелі і тягнеться у височінь, намагаючись досягти обителі богів - Валгалли. Його силует з покрученими лініями, стіни, що обриваються урвищами, гігантські валуни, що перетинають шлях, усі ці хаотичні площини і лінії сприймаються як повна протилежність «простору» бургундів. Небезпеки і непередбачуваності, котрі чатують на прибульців, додає море вогню, що оточує замок. Згасити його може лише справжній герой, тобто Зігфрід. Але коли буругнди втрачають його, ніщо не порятує їх від вогняної загибелі в замку короля гуннів Етцеля.

У тканину фільму вплетені кілька епізодів, які здаються ідилічними. Це, наприклад, зустріч закоханих Зігфріда і Крімгільди в квітучому саду. Тут Ланга чекали докори критиків у надмірній «солодкавості» цих кадрів. I разом з тим місце загибелі героя над джерелом привертає якоюсь меланхолійною красою. Стрункі молоді берізки були спеціально висаджені в павільйоні, так само, як квіти на галявині. Знімальна група Ланга терпляче чекала, поки вони зазеленіють.

Фінальні епізоди «Зігфріда» (перша частина дилогіi) звучать як скорботна мелодія, стримана i водночас урочиста. Тіло Зігфріда несуть до замку, вітер, що здіймається зненацька, колише біляве волосся героя, здіймає вихор пилу на мосту.

Лотте Айснер зауважує, що рухи неживих предметів - вітер, який колише і світло смолоскипів, і завіси в спальні Кримгільди, несе в собі небезпеку руйнації і загибель усього живого.

Та справжнім торжеством загибелі і хаосу стає фільм «Помста Кримгільди». Ланг створює апокаліптичну картину світу, де руйнуються всі людські зв'язки, де заради помсти сестра, перетворившись на мстиву фурію, вбиває братів, де звершуються справжні гекатомби в протистоянні бургундів і гуннів, а палац Етцеля перетворюється на палаючу Валгаллу, де вже ніхто не знаходить порятунку.

Показуючи підвладні Етцелеві племена гуннів, Ланг змушує виконавців вдаватися до пластики, яка принципово відрізняє їх від струнких, стриманих у своїх рухах лицарів-бургундів.
Як зауважують дослідники, Ейзенштейн в «Олександрі Невському» йшов від малюнка цих постатей до тевтонських лицарів у їх блискучих обладунках і білих плащах. I сам клиноподібний, геометрично точний рух лицарів теж примушує згадати масові сцени у Ланга, і не лише в «Нібелунгах», а й у «Метрополісі». Натомість гунни рухаються зігнувшись. Їхні руки майже сягають землі. Вдягнуті у шкури, вони виконують у своїх печерах біля вогнища дикунські танці.

До речі, сам Ейзенштейн мріяв поставити кіноепопею «Загибель богів», у якій він так само, як і Вагнер, прагнув через символіку «Загибелі богів» розвинути тему приреченості ненависної йому цивілізації, звичайно ж, буржуазної, капіталістичної. Режисер отримав можливість доторкнутися до образів епосу на оперній сцені.

Готуючи виставу опери Вагнера «Валькірія» в 1940 році у Большому театрі, видатний режисер виклав думки, породжені вагнерівськими образами в своїй статті «Втілення міфу», що повною мірою таїть у собі ключі до глибинних смислів «Нібелунгів».

Проте основний конфлікт «Валькірії» Ейзенштейн визначає дещо в іншому плані, йдучи тут також за Вагнером. Трагічна колізія будується на забороненому коханні Зігмунда та Зіглінди - батьків Зігфріда, які були братом і сестрою. «У трагічній історії кохання близнюків Зігмунда і Зіглінди відбився той історичній зсув у переході до впорядкованих форм подружнього життя i встановлення основ нормальної сім'”і, який і ліг в основу трагедії Едіпа» [7, 338].

Ейзенштейн розглядає три точки зору на події. Одна з них, що утверджує анархічне, природне начало, котре не визнає ні законів, ні норм, належить богові ураганів і бур Вотану. Йому протистоїть Фрікка, його дружина, богиня - покровителька домашнього вогнища. У зіткненні з нею і зазнає фіаско стихійність Вотана. I третя точка зору - це співчуття закоханим, яке виявляє валькірія Брунгільда.

Бездушна, формальна мораль Фрікки, на думку Ейзенштейна, $є$ засобом придушення вільної людської особистості. Авторові «Івана Грозного» надзвичайно імпонувала синтетичність вагнерівської музичної драми. Сам епос і стихія вагнерівської музики підказали Ейзенштейну шлях до втілення ідей синтетичного театрального видовища.

Режисер зауважує, що епос, який надихав Вагнера, народився в ті часи, коли людина не виділяла себе 3 довколишнього середовища, 3 природи. I, відповідно до цих поглядів, Вагнер при- 
мушує рівною мірою подавати на сцені людину і природу.

Ейзенштейн відчував, що музика Вагнера прагне бути зримою, видимою. А зримість ця має різку окресленість, чуттєвість, матеріальність.

Засоби зображального втілення мали, за задумом Ейзенштейна, розворушити у нашій свідомості ті пласти, в яких ще має місце мислення образне, поетичне, чуттєве і міфологічне. Митець у ті часи не міг цього висловити, але зрозуміло, що він апелював до позасвідомого, до тих архетипів, що закладені в його глибинних шарах.

Активність дії досягається іiї могутнім устремлінням вгору (згадаймо замок-скелю Брунгільди у Ланга). І для цього центральним образом, що дію цю організує, стане одвічне світове дерево, котре втілює дух природи.

Для Ейзенштейна участь природи в людській драмі була надзвичайно важливою: це і скелі, що обрушуються на воїнів, і дерева, які змітає буря, викликана Вотаном, і полум'я, що охоплює весь небосхил.

Як і у фільмі Ланга, у Ейзенштейна некеровані стихійні сили природи символізують розкуті пристрасті та визволені інстинкти.

Особливе місце в цьому ряду мав посісти політ валькірій, що його Ейзенштейн трактував як мімічний хор. Валькірії, нескорені й буйні, як їх батько Вотан, втілюють могутні природні стихії.

У своїх роздумах Ейзенштейн знов і знов повертається до архітектури сценічного простору, до пластично-образного звучання спектаклю.

«Ідея про декорацію як про образне підніжжя динамічного носія думок і почуттів діючої людини, що пластично втілює драматичний зміст музики, визначила форму декорації.

Декорації виявились наче тією частиною єдиного динамічного вихору, що його викликала до життя музика; тією частиною, на долю якої випало застигнути в сценічному просторі станками $\mathrm{i}$ фарбами, сходами і урвищами, поверхнями і площинами, щоб служити опорою дії і вчинкам артистів» $[7,356]$.

Як бачимо, осмислюючи Вагнера, хоча б і на оперній сцені, а не на екрані, Сергій Ейзенштейн робив акцент на тих моментах, що ми їх знаходимо у фільмі Ланга, а саме на протистоянні стихії природних пристрастей та інстинктів, котрі «виплескують» 3 надр позасвідомого і суворих вимог моралі, що вже склалась у надрах суспільства.

Проте в розробленні планів постановки вагнерівської опери, російський режисер пропонував «третю точку зору», яка протистояла як анархіч- ній, так і тоталітарній і являла собою позицію толерантності.

Декорація, тобто відтворення середовища, архітектура, як відображення настроїв і світобачення як суспільства, так і окремої особистості, відіграє у Ейзенштейна, як і в Ланга, надзвичайно вагому роль. Архітектурні споруди набувають знакового, символічного характеру в його німих шедеврах: сходи у «Панцернику “Потьомкіні"», Зимовий палац у «Жовтні».

Та Ейзенштейна, як митця нової доби, теж цікавили будови майбутнього, і численні творчі плани, зокрема такий сценарій, як «Скляний дім», $\epsilon$ вагомим свідченням захоплень видатного майстра. I хоч Ейзенштейнові не вдалося втілити свої задуми і створити на екрані футурологічні образи мегаполіса, він дав чимало корисних порад своєму німецькому колезі Фріцові Лангу, коли той узявся до роботи над своїм «суперпроектом» «Метрополіс».

«Містика архітектури» проявлялась у творчості німецького кіномитця, художника й архітектора за освітою майже у всіх його картинах німого періоду. Як зазначалось, архітектурна споруда набирає особливого символічного значення вже в його стрічці «Стомлена смерть».

У «Метрополісі» художник і архитектор фільму О.Гунте надихатиметься образом Вавилонської башти Брейгеля, коли створюватиме в павільйонах УФА циклопічні будівлі міста майбутнього. Це йому присвячено вислів Л. Бунюеля: «Кіно - надійний інтерпретатор мрій архітектури». Щоправда, гігантські хмарочоси не відтворювались у натуральну величину. Став у пригоді так званий ефект Е. Шюфтана, коли за допомогою складної системи дзеркал невеликі макети набували вигляду колосальних споруд.

Поштовхом для втілення грандіозної антиутопії про місто майбутнього стала нічна панорама Нью-Йорка, яку Ланг спостерігав $з$ борту пароплава.

Його ідеї захопили Теа фон Гарбоу, яка і взялась до написання сценарію. Згодом Ланг пригадував, що досить тривіальний сюжет був лише приводом для відтворення картин майбутнього, йому імпонували «вибухові ритми могутньої ходи прогресу».

Сюжет хоч і був фантастичним, проте в цілому відповідав соціальним запитам повоєнної епохи, коли класові зіткнення давали привід замислитися про неминучість компромісів.

У сценарії Т. фон Гарбоу розв'язання класових конфліктів пропонувалося на досить-таки ме- 
лодраматичному й наївному рівні. Син тирана-фабриканта, хазяїна підземних заводів Метрополіса, закохується у дочку робітника Марію, їх кохання і стає реалізацією заклику поєднання рук, тобто робітників, і мозку, фабрикантів, через серце, через любов.

Та облишмо сюжетні перипетії, якими не надто переймався сам Ланг.

Як же бачив сам режисер отой мегаполіс майбутнього, в якому напрямку цивілізація спрямовувала свою ходу?

Саме місто поділене на дві частини. Над землею здіймаються хмарочоси, а в глибинах надр розташовані колосальні заводи, на яких вдень i вночі працюють тисячі робітників. Мешканці верхнього міста насолоджуються всіма благами життя, і одне 3 них - чи не найцінніше - можливість спілкування 3 природою. Виявляється, поміж кам'яним нагромадженням хмарочосів, обплутаних, як павутинням, підвісними дорогами, якими мчать авто, збереглися райські куточки, доступні лише обранцям долі. До речі, відгомін декораційних побудов у Ланга знаходимо в стрічці Л. Бессона «П'ятий елемент».

Отже, доступ до природи, до розкішних парків 3 екзотичними деревами, джерельцями і фонтанами можливий лише для обраних. Всім іншим - залишається вічний гуркіт машин, чиї ритми наче керують ритмами рухів самих робітників. Робітники - раби машин, техніка виступає як жорстокий і всевладний Молох. Тут слід зауважити, що, показуючи колосальні палаючі печі на підземному виробництві, режисер прямо цитує кадри з фільму Д. Пастроне «Кабірія», де в страшенну вогненну пащу ідола Молоха в Карфагені вкидають нещасні жертви.

Маси людей, неначе спресовані в геометричні форми, рухаються в заданому ритмі. Робітники, які обслуговують техніку, включаються 3 нею в нерозривну єдність, стають немовби частиною іiі. Рух колон на підземних заводах нагадує орнамент тією самою мірою, що й воїни Гунтера чи лицарі Зігфріда в «Нібелунгах», коли вони нерухомо застигають на сходах або на вежах замку, перетворюючись на живі скульптури. «Маси шикувалися в цьому фільмі в гігантський балет», - зауважував Л. Бунюель.

На думку Лотте Айснер «Ланг використовує елементи експресіоністського стилю зображення безликої людської маси в підземному світі робітників. Він показує позбавлені будь-якої індивідуальності людські створіння, котрі звикли ходити 3 опущеною головою і понуро похиленими пле- чима. Вони переможені ще до того, як розпочали боротьбу. Це раби, а всі раби в усі часи виглядають однаково. Стилізація досягає найвищої точки в епізоді зміни робітничих бригад, коли зустрічаються дві колони, що крокують в однаковому ритмі й утворюють рівні прямокутники: в цій масі вже неможливо виділити окрему людину, отож здається, що вона не існує» $[1,117]$. Власне, в кінематографі у Ланга був попередник у такій виразній побудові масових сцен. Це Отто Ріпперт. У його фільмах про Гомункулуса, де натовп, що прямує за Гомункулусом по сходах, рухається у геометричній формі трикутника.

Архітектура підземного міста ніби акомпанує тій убивчій «геометричності», в якій змушені рухатися люди. Куби будинків 3 темними вікнами, симетрія сходів та дверей і $€$ тим місцем, де мають жити ці перетворені на автомати створіння.

Проте не тільки грандіозні картини мегаполіса майбутніх часів у фільмі німецького кіномитця примушують замислитись над есхатологічною перспективою подальшого ходу цивілізації, що підтверджується майстерно знятими кадрами катастрофи на підземних заводах, коли безжальні потоки води поглинають тисячі робітників. «Метрополіс», так само як і фільми про тиранів, продемонстрував «візіонерський» талант Ланга. Постаті рабів підземного міста примушують згадати, як у наступному десятилітті Німеччина побачить такі самі колони невільників, що шикуватимуться на плацах концентраційних таборів. I не лише Німеччина. Йшли валки приречених на Соловки, на будівництво Біломорканалу, інші «острови» страшного «архіпелагу ГУЛАГ».

Як уже зауважувалось, опозиція «природа i культура» виникає не лише в макромасштабах, а й на рівні окремої особистості. Саме так іiї вирішували німецькі експресіоністи, Ланг зокрема. I, наслідуючи традицію романтизму, розглядали драматичні колізії протистояння природного і штучного, виводячи на екран постать штучної людини.

До речі, у висвітленні сюжетів, пов'язаних 3 появою особистості, що прийшла у світ неприродним шляхом, рішуче розходилися шляхи експресіоністів і тих митців, що представляли революційний авангард, російський зокрема. Взяти хоча б поезію і драматургію Маяковського. В його «Бані» 3'являється посланець майбутнього «фосфорична» жінка, яка покликана здійснити рішучу «чистку» суспільства від всілякої соціальної «нечисті».

«ФЕКСи» - М. Козинцев і Л. Трауберг залишили нереалізований сценарій «Електрична 
жінка», де видатний американський винахідник Т. Едісон дарує світові своє нове створіння. Звичайно, сам винахід було показано в притаманній ФЕКСам ексцентричній манері.

«Едісон в кріслі - ззаду. Сидить на колбі $з$ киплячою водою. У воді величезне яйце.

Що висиджує Едісон?» [3, 88]

Далі вибух — i з'являється міс П.К. В. Вона наділена чудесною силою приводити в рух будьякі прилади і машини. Та винахідник-капіталіст робить фатальну помилку: до колби, де зародилася чудесна міс, потрапив клаптик газети «Правда». Тому в її голівці оселились комуністичні ідеї. Вона полишає буржуазну Америку і поспішає до батьківщини всіх трудящих - СРСР. Опинившись у Петрограді, штучна міс називає себе Октябриною і починає безжально боротися із залишками старого побуту, який бурхливо проростає на НЕПівському грунті.

На відміну від ФЕКСів, Ланг виводив на екрані свою штучну жінку, попередницю сучасних роботів, як відверте втілення зла. Жінка, створена в лабораторії божевільного вченого, виступає не сама по собі. Вона є двійником Марії (актриса Брігітта Хелм). Однак якщо Марія - втілення всіх християнських чеснот, то іiі робот-двійник носій злого начала,

Марія, дочка робітника, яка закохана в сина власника підземних заводів, жорстокого тирана i визискувача, готова зробити все, аби запобігти кровопролиттю і переконати робітників мирно вирішити всі свої суперечності з хазяїном. Та іiі двійник Марія-робот виступає як провокатор, підбурюючи робітників до повстання. Треба віддати належне і режисерові, i, звісно, актрисі, які зуміли знайти надзвичайно точне пластичне рішення, щоб глядач зміг відрізнити Марію, живу людину із крові і плоті, від Марії-робота, запрограмованого на зло. Якщо в образі першої Б. Хелм рухається трохи повільно, жести ії стримані й «округлі», то механічна Марія вже першою появою демонструє свою спорідненість 3 машинами і механізмами. Коли безумний учений створює подобу дочки робітника, навколо іiі постаті виникає світіння, що має підтвердити іï штучне походження. Ї̈і рухи різкі і свавільні. Вона, здається, виконує якийсь магічний танок, що заворожує, тягне за собою, неначе у прірву, очманілий натовп. Це машина, яка покликана збуджувати у людській юрмі первісні небезпечні інстинкти руйнації та варварства. Розлючені робітники, здогадавшись про небезпечні провокації Марії-робота, вирішують її стратити як середньовічну відьму, спаливши на вогнищі. Про- те ця акція не сприймається як справедливе воздаяння злу. Навпаки, зло торжествує свою перемогу, бо примусило людей об'єднатися для жорстокого садистського вчинку. Думка автора про марність спроб за допомогою зла подолати зло досить точно розкривається в кадрах, коли «штучна» Марія, стоячи на палаючому вогнищі, заходиться зловісним сміхом.

Займається і згорає разом з одягом ііі людська подоба, і серед вогню виникає металева конструкція, якій не страшне жодне полум'я. (Як тут не згадати славнозвісного Шварценеггера-Термінатора.)

Образ Марії-робота, його зображальне вирішення було навіяно творами відомого скульптора-авангардиста Рудольфа Беллінга.

На думку Жіля Дельоза, в експресіоністських стрічках «...автомати, роботи і маріонетки являють собою вже не механізми, що наголошують кількість руху або перебільшено його оцінюють, а сомнамбул, зомбі або големів, що виявляють інтенсивність такого неорганічного життя» $[2,100]$.

У «Метрополісі» Ланга добро зрештою перемагає зло, досягається гармонія соціальних стосунків у суспільстві. Така концепція страшенно дратувала «лівих» критиків режисера, та й сам він уважав їі малопереконливою.

Життя показало, що не так вже й помилялися автори «Метрополіса». Вже в XXI столітті з'явились у світі «острівці» цієї соціальної гармонії, як-от країни Північної Європи.

Завершивши «Метрополіс», найдорожчий фільм у німому німецькому кінематографі, Ланг до кінця 1920-х років зніме ще два фільми. «Шпигуни» (1928 р.) змусять пригадати його ранні пригодницькі стрічки, а от «Жінка на Місяці» (1929 р.) зверне на себе увагу як фільм-предтеча майбутніх стрічок про підкорення космосу. Сьогодні особливо вражає епізод підготовки космічної ракети до старту. Над спецефектами для фільму працював відомий авангардист Оскар Фішінгер.

Лангові пропонували знімати «Жінку на Мiсяці» як звуковий фільм, та режисер відмовився. Він із певним запізненням прийшов у звукове кіно, втім, одразу продемонстрував високу майстерність в оволодінні новим виражальним засобом. Фільм «М (Убивця)» на думку Ейзеншица «шедевр структури, в якій усі деталі зчеплені одна 3 одною, де зображення і звук підхоплюють естафету і нероздільні одне з одним» $[6,43]$.

Відомий історик кіно вважає, що “"М” - вузол німецького кіно. Це вершина роботи над формою оповіді, котра йшла протягом п'ятнадцяти 
попередніх років. Важко не виявити вплив "М" повсюдно, незважаючи на періодичні напади амнезії, котрими було позначені п'ятдесят наступних років» $[6,44]$.

У своїй наступній роботі митець, продовжуючи своє дослідження природи зла, ще більше наближається до виявлення його соціального коріння. В картині «Заповіт доктора Мабузе» (1933) містичний злочинець у могилі продовжує діяти через своїх послідовників, які охоче втілюють у життя його ідеї. У фільмі віддзеркалюється моторошна картинка злочинності та хаосу, що охоплюють суспільство перед приходом нацистів до влади. Тому цілком зрозуміло, що фільм було заборонено. Як уже згадувалося, Ланг отримав від самого Гебельса пропозицію очолити німецьку кінематографію. Та митець обрав інше. Він їде до Франції і затим у США, де приєднується до лав антифашистської еміграції.

Робота Ланга в Голлівуді - окрема і надзвичайно плідна і цікава сторінка кінобіографії митця. Його творчість залишила відбиток майже в усіх жанрах. Та, починаючи з фільму «Лють» (1936р.), режисер прагнув показати, наскільки небезпечні прояви фашизму, що можуть виявлятися і в благополучних демократичних суспільствах.

Він поставив стрічки, де безпосередньо йшлося про злочини нацизму («Полювання на людину», «Кати теж вмирають»). Як і інші режисери-емігранти, Ланг долучиться до розробки жанру «нуар», створивши такі блискучі його взірці, як «Жінка у вікні», «Вулиця гріха» та інші.

Ланг висловлював своє захоплення вестернами: «Так, я люблю вестерни. Вони мають у собі необхідну мораль. Їх я поставив три: "Повернен- ня Френка Джеймса”, “Ранчо з поганою славою”, “Вестерн-Юніон”» [5, 55].

I все ж режисер, прибувши до Німеччини в 1960 році, повернеться до свого старого персонажа, знявши фільм «Тисяча очей доктора Мабузе». Тепер містичному злочинцеві слугує новітня техніка і насамперед телебачення. В цьому Ланг став свого роду провидцем - сьогодні медіа $€$ одним 3 найнебезпечніших видів зброї.

На початку 60 -х років кіноглядачі мали можливість побачити Фріца Ланга в ролі самого Фріца Ланга. В стрічці Годара «Зневага» (1963 р.) знаменитий режисер висловлював свої думки щодо кінематографа і мистецтва в цілому. Це прозвучало майже як заповіт митця, який пройшов у кіно унікальний за своєю плідністю й успішністю шлях.

\section{Джерела та література}

1. Айснер Л. Демонический экран // Лотте Айснер. - М. : Пост Модерн Текнолоджи, 2010.

2. Делез Ж. Кино // Жиль Делез. - М. : Ад Маргинем, 2004. - $622 \mathrm{c}$.

3. «Женщина Эдисона». Первый сценарий фэксов // Киноведческие записки. - М. : ВНИИ киноискусства, 1990. - Вып. 7.

4. Кракауер 3. Від Калігарі до Гітлера - психологічна історія німецького кіна / Зігфрід Кракауер ; [пер. 3 нім. І. Андрущенка]. — К. : Грані-Т, 2009. — 381 с. — (Cepiя «De profundis»)

5. Ланг Ф. Венская ночь / Фриц Ланг // Киноведческие записки. - М. : НИИ Киноискусства, 2002.

6. Эйзеншиц Б. Немецкое кино. 1895-1933 / Бернар Эйзеншиц // Киноведческие записки. - М. : НИИ киноискусства, 2002. - Вып. 58.

7. Эйзенштейн С. Поэтика мифа. Избр. произв. : в 6-ти т. / С. М. Эйзенштейн. - М. : Искусство, 1968. T. 3. 